\title{
Educational and evaluation strategies in the training of physician specialists
}

\author{
Verónica Alejandra Gaona-Flores', Luz Arcelia Campos-Navarro², Jesús Arenas-Osuna³ \\ and Enrique Alcalá-Martínez' \\ 'Infectology Hospital; '2General Hospital; ${ }^{3}$ Specialty Hospital Centro Médico Nacional La Raza, Ciudad de México, Mexico
}

\begin{abstract}
Background: Teaching strategies have been defined as procedures, means, or resources that teachers used to promote meaningful learning. Aim: Identify teaching strategies and evaluation used by the professor with residents in tertiary hospitals health care. Methods: This is a cross-sectional study conducted with full, associate, and assistant professors of various medical specialties. A questionnaire was applied to evaluate the strategies used by professors to teach and evaluate students. Results: We included a sample of 90 professors in 35 medical specialties. The most frequent teaching activities were organizing students to develop presentations on specific subjects, followed by asking questions on previously reviewed subjects, in terms of the strategies employed, the most frequent "always" option was applied to case analyses. The most frequent methods used for the evaluation of theoretical knowledge were participation in class, topic presentation, and examinations. Conclusions: Teaching activities were primarily based on the presentation of specific topics by the residents. The most commonly used educational strategies were clinical case analyses followed by problem-based learning and the use of illustrations. Evaluation of the residents' performance in theory knowledge, hinged on class participation, presentation of assigned topics, and examinations.
\end{abstract}

KEY WORDS: Education. Medical education. Educational strategies. Learning assessment.

\section{Introduction}

Clinical teaching directly involves patients and constitutes the core aspect of education in the field of health. The teaching-learning process in medical education is highly important; it is from it that the trainee doctor obtains abilities to solve the problems posed by medical care'.

Thus, this learning focuses on real problems in the context of professional practice and, this way, students are motivated by their participation in the solution of these problems. Typical teaching involves the supervision of the student on training by a clinician with greater experience; generally, this involves the resident with the highest hierarchy or the assistant professor, which results in a wide variety of teaching styles. An important aspect to be highlighted in this scenario is that an important part of teaching is obtained from the example offered by the teachers of that moment ${ }^{2}$.

In the face of resident physicians' expectations, which are multiple, it would appear that an efficacious teacher is that who is able to satisfy the students' academic needs. The resident's performance depends on conditions that the teacher must know how to recognize and identify; some factors are the curricular

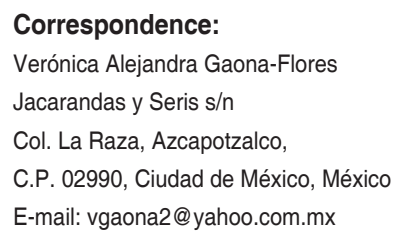

Date of modified version reception: 09-05-2016

Date of acceptance: 09-05-2016

DOI: 10.24875/GMM.M17000030
Gac Med Mex. 2017;153:459-465

Contents available at PubMed www.gacetamedicademexico.com 
ones and those associated with the student's learning style. Teaching style is conceptualized as the behavior, the teacher exhibits at each phase or moment of the teaching activity, which is founded on personal attitudes that are characteristic of him/her, that have been abstracted from academic and professional experience, that do not depend on the contexts where they are shown, and that can increase or decrease inconsistencies between teaching and learning ${ }^{3}$. These elements make up a teaching and learning style; we cannot determine only one style of one or the other; generally, it is heterogeneous and even changes with each student, classroom or clinical situation. This behavior is dynamic since teaching implies knowing the student, his/her personality, his/her intelligence, his/ her intellectual, and emotional strengths or weaknesses, the reasons that guide his/her learning, and this enables the teacher to create an appropriate atmosphere for the process of learning and teaching 4 .

There is no ideal teaching style that is agreeable to all students since the relationships between teaching styles and learning are complex and there is substantial individual variability.

Teaching strategies have been defined as procedures, means, or resources that the teacher uses in a reflexive and flexible form to promote the achievement of meaningful learning. It is important to identify that didactics is conditioned by the specificity of the specialty's own curriculum ${ }^{5}$. In a consecutive form in the teaching-learning process, there is evaluation, understood as a variable that supports, among others, the teacher's own criteria in the evaluation of learning, coherence, or academic feedback ${ }^{6,7}$.

Some studies have been conducted on the relationship between the teacher's teaching style and students' learning style. It stands out that each student has a learning style of his/her own that is independent of the faculty teaching style, and that is not directly related to student performance, although it has been possible to identify that they prefer teaching methodologies that are more student-centered ${ }^{8}$. Another publication identified that fortifying the residents' attitude and motivation to study is required, and thereby offering courses on study techniques ${ }^{9,10}$.

Evaluation is a teaching strategy that allows for the educational process to be verified. In general, it is carried out by means of observation and student-teacher interrelation in clinical practice to subsequently qualitatively or quantitatively express the obtained result; this appears as a challenge for the teacher. For the evaluation to be interpreted, the goals to be achieved by the student should be defined, and the objectives of the course to achieve the performance skills have to be reported.

The diagnostic, summative, and formative evaluation is the formal evaluation that has to be carried out through evaluation formats or instruments, even with checklists that facilitate the recording of information obtained for each student in the field of cognitive, procedural, and attitudinal competencies ${ }^{11,12}$.

Under these elements, arose the research question for this study, which are the educational and evaluation strategies by means of which specialist physicians are trained at tertiary care hospitals from a national medical center? Thus, our objective was to identify the teaching and evaluation strategies a teacher uses with residents at tertiary care hospitals.

\section{Methods}

This was a descriptive, cross-sectional observational study that was carried out at the Centro Médico Nacional La Raza from January to June 2015 with full, associate, and assistant teachers of different medical specialties who agreed to participate; they were verbally invited by reading an informed consent script to answer a questionnaire on the educational and evaluation strategies used with residents. The meeting place to apply the questionnaire was the hospital auditorium, and it took them approximately 10 min answering it.

The instrument was provided by the author of a study conducted at the Faculty of Dentistry of the Universidad Nacional Autónoma de México. The result of the internal consistency analysis with Cronbach's alpha was 0.880 , which established that the instrument was reliable. It was composed of three sections assessing the strategies used by the professor for teaching and the form to evaluate the students. The discrimination of responses was through scores in a Likert-type scale with four options: never, almost never, almost always, and always ${ }^{13}$.

\section{Statistical analysis}

Descriptive statistics were carried out with absolute numbers and percentages.

\section{Ethical aspects}

The study was submitted to the Instituto Mexicano del Seguro Social (IMSS) Local Committee of Health Research. According to criteria of the General 
Statutes of Health in Matters of Health Research Rulebook, second title "On ethical aspects of research in human beings," only chapter, article 17 , subsection I, and the protocol is regarded as risk-free research. Moreover, according to the rule that establishes the regulations for health research at the IMSS, "personnel that perform health research activities at the IMSS should carry them out with adherence to national and international ethics codes."

\section{Results}

A total of 101 questionnaires were handed out (Appendix I) and 90 were returned, which were the total sample, out of which $56.7 \%$ were assistant, $24.4 \%$ were associate, and only $18.9 \%$ were full professors. As for medical specialties, those that participated in larger number were internal medicine with $12.2 \%$, medical pediatrics with $8.9 \%$, otorhinolaryngology with $7.8 \%$, pediatric cardiology with $6.7 \%$, and pulmonology with $5.6 \%$ (Table 1).

With regard to the question about the teaching activities most often practiced by the teacher, these were organizing the students for the presentation of topics, $52.2 \%$ answered that always, followed by asking questions about previously addressed subjects, with $44.4 \%$ always doing it. Of the same question, the option "never" was more commonly observed for dictation, with $82.2 \%$, followed by asking the students to discuss subjects previously exposed by the teacher, with $43.3 \%$.

In the question referring to educational strategies used by teachers, the most common "always" choice was for analysis of cases with $55.6 \%$, followed by problem-based learning with $42.2 \%$, and at third place illustrations with $15.6 \%$. In this same question, the "never" answer was chosen more frequently for simulation with $41.1 \%$, summaries with $34.4 \%$, and advance organizers with $25.6 \%$.

With regard to the answers to the question referring student performance evaluation, the most widely used evaluation methods were found to be participation in class $(65.6 \%)$, exposition of topics by students $(57.8 \%)$, and examinations (46.7\%). Evaluation strategies that were never used included the resolution of study guides $(45.6 \%)$, extra-class works $(26.7 \%)$, and conceptual maps (16.7\%) (Table 2).

\section{Discussion}

Teaching activities are an essential element of the learning process. The training of the specialist
Table 1. Participating physicians by specialty

\begin{tabular}{|c|c|c|}
\hline Specialty & No. & $\%$ \\
\hline Internal medicine & 11 & 12.2 \\
\hline Medical pediatrics & 8 & 8.9 \\
\hline Communication-audiology & 7 & 7.7 \\
\hline \multicolumn{3}{|l|}{ Otoneurology } \\
\hline Otorhinolaryngology & 7 & 7.8 \\
\hline Pediatric cardiology & 6 & 6.7 \\
\hline Pulmonology & 5 & 5.6 \\
\hline Anesthesiology & 4 & 4.4 \\
\hline Rheumatology & 4 & 4.4 \\
\hline Pediatric rheumatology & 3 & 3.3 \\
\hline Anatomic pathology & 2 & 2.2 \\
\hline Dermatology & 2 & 2.2 \\
\hline Medical genetics & 2 & 2.2 \\
\hline Critical medicine & 2 & 2.2 \\
\hline Neonatology & 2 & 2.2 \\
\hline Neurology & 2 & 2.2 \\
\hline Ophthalmology & 2 & 2.2 \\
\hline Clinical pathology & 2 & 2.2 \\
\hline Urology & 2 & 2.2 \\
\hline Other clinical specialties & 17 & 18.9 \\
\hline
\end{tabular}

physician demands for certain abilities to be acquired according to the specialty, which is accomplished by in principle using and making the most of the student's previously acquired mental processes, habits, and attitudes with regard to study, in addition to adapting to the learning style and the faculty teaching style throughout the specialty training ${ }^{14,15}$.

In this study, as other authors have done, a wide variation between teaching styles was identified; in light of this, heterogeneity in the quality of teaching is likely to be found ${ }^{16}$. We have to identify the importance of balancing the relationship between what is taught and how is it learnt by physicians; i.e. the content in contrast with the process. This way, it is important for the learning strategies that predominate for the group of physicians, both students and teachers, to be identified ${ }^{17}$.

In this work, we found that most teachers organize the students in order for them to prepare and expose topics and that they ask questions about previously addressed subjects. 
Educational strategies referred as "always" or "almost always" being used include conceptual maps, synoptic charts, and diagrams. Analysis of clinical cases and problem-based learning stood out, suggesting that the results of this strategy will be the product of the experience acquired over the years of previous training, where theory can be applied in the clinical field, with an addition of knowledge on precedents being made through activities such as presenting and developing subjects of the curriculum. This way, in the sessions with clinical cases, the analysis of those residents with larger number of years of study in the specialty has a better profile.

For this study, we resorted to the instrument used by Espinoza-Vázquez et al. ${ }^{13}$, who reported, unlike this work, that teachers in their study preferred exposing topics and asking questions on addressed subjects, and among their teaching-learning strategies, they

Table 2. Teaching-learning methods used by medical teachers

\begin{tabular}{|c|c|c|c|c|}
\hline In the courses, you teach, indicate how often do you & $\begin{array}{l}\text { Never } \\
\text { No. (\%) }\end{array}$ & $\begin{array}{l}\text { Almost never } \\
\text { No. (\%) }\end{array}$ & $\begin{array}{c}\text { Almost always } \\
\text { No. (\%) }\end{array}$ & $\begin{array}{l}\text { Always } \\
\text { No. (\%) }\end{array}$ \\
\hline \multicolumn{5}{|l|}{ Carry out the following activities } \\
\hline I expose topics & $21(23.3)$ & $30(42.2)$ & $26(28.9)$ & $4(4.4)$ \\
\hline I organize the students to expose topics & $1(1.1)$ & $7(7.8)$ & $35(38.9)$ & $47(52.2)$ \\
\hline I dictate & $74(82.2)$ & $13(14.4)$ & $1(1.1)$ & $2(2.2)$ \\
\hline I organize group dynamics & $6(6.7)$ & $18(20)$ & $45(50)$ & $20(22.2)$ \\
\hline I ask questions about previously addressed subjects & $2(2.2)$ & $4(4.4)$ & $41(45.6)$ & $40(44.4)$ \\
\hline I ask the students to discuss topics previously exposed by me & $39(43.3)$ & $13(14.4)$ & $21(23.3)$ & $15(16.7)$ \\
\hline I ask the students to discuss based on previous readings & $12(13.3)$ & $9(10)$ & $42(46.7)$ & $27(30)$ \\
\hline \multicolumn{5}{|l|}{ Do you use the following teaching strategies? } \\
\hline Advance organizers & $23(25.6)$ & $32(35.6)$ & $28(31.1)$ & $7(7.8)$ \\
\hline Summaries & $31(34.4)$ & $34(37.8)$ & $20(22.2)$ & $5(5.6)$ \\
\hline Conceptual maps & $14(15.6)$ & $19(21.1)$ & $47(52.2)$ & $9(10)$ \\
\hline Illustrations & 17 (18.9) & $28(31.1)$ & $31(34.4)$ & $14(15.6)$ \\
\hline Diagrams & $16(17.8)$ & $23(25.6)$ & $40(44.4)$ & $11(12.2)$ \\
\hline Synoptic charts & $15(16.7)$ & $29(32.2)$ & $36(40)$ & $10(11.1)$ \\
\hline Analogies & $22(24.4)$ & $27(30)$ & $30(33.3)$ & $9(10)$ \\
\hline Demonstrations & $17(18.9)$ & $25(27.8)$ & $31(34.4)$ & $16(17.8)$ \\
\hline Problem-based learning & $2(2.2)$ & $3(3.3)$ & $47(52.2)$ & $38(42.2)$ \\
\hline Analysis of cases & 0 & $1(1.1)$ & $38(42.2)$ & $50(55.6)$ \\
\hline Simulation & $37(41.1)$ & $26(28.9)$ & $20(22.2)$ & $7(7.8)$ \\
\hline \multicolumn{5}{|l|}{$\begin{array}{l}\text { To evaluate the performance of your students in theoretical aspects, } \\
\text { do you employ the following procedures? }\end{array}$} \\
\hline Extra-class works & $24(26.7)$ & $35(38.9)$ & $22(24.4)$ & $9(10)$ \\
\hline Evidence portfolio & $14(15.6)$ & $25(27.8)$ & $34(37.8)$ & $16(17.8)$ \\
\hline Examinations & 0 & $14(15.6)$ & $34(37.8)$ & $42(46.7)$ \\
\hline Conceptual maps & $15(16.7)$ & $19(21.1)$ & $45(50)$ & $11(12.2)$ \\
\hline Exposition of topics by students & 0 & $4(4.4)$ & $34(37.8)$ & $52(57.8)$ \\
\hline Participation in class & 0 & $2(2.2)$ & $28(31.1)$ & $59(65.6)$ \\
\hline Resolution of study guides & $41(45.6)$ & $31(34.4)$ & $9(10)$ & $8(8.9)$ \\
\hline
\end{tabular}


use demonstrations, illustrations, and analysis of cases; with regard to evaluation, they choose participation in class and multiple choice examinations.

Other authors emphasize that strategies, by themselves, do not directly lead to academic success, but the motivation, the student chooses his/her learning with is a necessary and influential condition, as well as the teacher's academic attitude ${ }^{18,19}$.

It is essential for the student to reflect on the obtained information, to critically analyze it; it is not enough for him to acquire information since its interpretation allows identifying the teaching-learning process and evaluation constituted as an integral element of this process ${ }^{18}$. The performance of knowledge examinations and individual feedback has helped medical students on their self-regulation cycle and the teacher to carry out the evaluation of the entire educational process, to dynamically modify, if necessary, the used strategies ${ }^{20-22}$.

The authors of this study identified that evaluation was circumscribed to assessing the command of specialty-specific knowledge. In contrast, in the evaluation by competencies, in addition to considering this proficiency, the development of performance on the cognitive, attitudinal, and affective-motivational dimensions is also appraised, for which purpose initially defining the competency between that what has been learnt and that what can be accomplished has been proposed $^{12,23}$.

This way, in the link between the teacher and student's participation, the latter, to study a medical specialty, is required to already be a graduated health professional, with learning strategies of his/her own, and should adapt to the teacher's educational strategies. We also cannot exclude that current generations' students use technological tools that significantly influence on their knowledge, at least on immediate learning. This way, it is important for technological access and abilities students possess to be linked with teachers' teaching style, thus facilitating the learning process and acting as a role model ${ }^{24}$. It is not enough thinking that we are doing things right, but we have to put them to test. Accepting the limitations in the results is the first step in defining strategies to improve the educational process, students' clinical refinement, patient safety, and health-care quality. This change appears to be associated with advanced teaching training, and this strength is most likely the way to improve postgraduate educational processes. Moreover, the thing is that, within the field of medicine, investigators have recognized the importance of self-regulation for effective clinical practice ${ }^{22,25,26}$. With a participative vision, favoring students' motivation, triggering and channeling initiative, and inventiveness is sought by promoting an experience mediated by critical thought in the generation of knowledge; it is a process where both teacher and student interact, enrich each other and generate and transform knowledge.

One aspect identified as a weakness in this study was the fact that, among the teachers of medical specialties who participated in this research, those involved with clinical areas predominated over those with surgical specialties. With the obtained results, we interpreted that they pay more importance to practice with the analysis of clinical cases, which were identified as an educational strategy over activities such as asking questions with regard to previously addressed subjects.

In this $21^{\text {st }}$ century, there is another challenge that remains to be addressed: setting out some considerations for reflection and alternatives of action around teaching in medical specialties. In the face of growing concerns for patient safety in the hospital setting, questionings have arisen on how efficacy is acquired from health-care professionals' practical experience. Currently, there is simulation-based education by means of technological equipment with educational technologies that have proven to be efficient in promoting the generation of knowledge ${ }^{27}$, without this stopping the teacher-student interaction to exist.

\section{Acknowledgments}

To all medical teachers who contributed with their time and answers to this study.

\section{References}

1. Chan D. Validation of the clinical learning environment inventory. Western Journal of Nursing Research. 2003:5:519-32.

2. Palacios GM, Quiroga LP. Percepción de los estudiantes de las características y comportamientos de sus profesores asociados a una enseñanza clínica efectiva. Estudios Pedagógicos. 2012;1:73-87.

3. Martínez GP. Aprender y enseñar: los estilos de aprendizaje y de enseñanza desde la práctica del aula. Bilbao, España: Mensajero; 2008.

4. Zhang L, Sternberg RJ. The nature of intellectual styles. $2^{\text {nd }}$ ed. USA: Education 2012

5. Díaz-Barriga AF, Hernández RG. Estrategias docentes para un aprendizaje significativo. Una interpretación constructivista. $2^{a}$ ed. México: McGraw Hill; 2002. Citado en: Palacios GM, Quiroga LP. Percepción de los estudiantes de las características y comportamientos de sus profesores asociados a una enseñanza clínica efectiva. Estudios Pedagógicos. 2012;1:73-87.

6. Stein GE. Eficacia docente en la educación odontológica. (Consultado el 10 de mayo de 2015.) Disponible en: http://www.odontologiaactual. com/eficacia-docente-en-la-educacion-odontologica.

7. Bello BS. Elementos a considerar por el docente clínico en odontología para la elaboración de estrategias de enseñanza clínica. Ciencia Odontológica. 2012;9:112-22.

8. García-Jiménez EP, Rojas-Pérez EM, Ruiz-Ruisanchez A. Técnicas de estudio para mejorar el aprendizaje en la residencia médica. Rev Mex Anestesiología. 2012;35:S242-4. 
9. Arias CM, Cano PE, Torres LJ. Estrategias de aprendizaje de los residentes en medicina general integral del Centro Oftalmológico José Martí. Educ Med Sup. 2010;24:223-39.

10. Aguilera PE. Los estilos de enseñanza, una necesidad para la atención de los estilos de aprendizaje en la educación universitaria. Journal of Learning Styles. 2012;10:79-87. (Consultado en octubre de 2015.) Disponible en: https://dialnet.unirioja.es/revista/12944/V/10.

11. Sánchez SA, Cisterna CF. La evaluación de los aprendizajes orientada a desarrollo de competencias en odontología. Educ Med Sup. 2014;28:104-14

12. McDonald R, Boud D, Francis J, et al. Nuevas perspectivas sobre la evaluación. Boletín Cinterfor. 2000;149:41-72. (Consultado en abril de 2015.) Disponible en: http://www.oitcinterfor.org/sites/default/files/file_articulo/rodajog.pdf

13. Espinoza-Vázquez O, Martínez-González A, Díaz-Barriga F. Formas de enseñanza y evaluación utilizadas por los docentes de odontología: resultados y su clasificación psicopedagógica. Inv Edu Med. 2013;2:183-92.

14. Lifshitz A. La enseñanza de la competencia clínica. Gac Med Mex. 2004;140:312-3.

15. Gaona-Flores VA, Campos-Navarro LA, Alcalá-Martínez E. Transformative learning between the student and the teacher? Concerning the learning styles of medical residents. Global Advanced Research Journal of Medicine and Medical Science GATMMMS. 2014;31:445-50.

16. Cid CS. El uso de estrategias de aprendizaje y su correlación con la motivación de logro en los estudiantes. REICE. 2008;6:100-20.

17. Estrada-Valenzuela CM, Prado-Mendoza JJ, De la Fuente-Cabrera LP, et al. Eficacia de estrategias de aprendizaje utilizadas por alumnos de la Facultad de Odontología de la Universidad Autónoma de Coahuila. Unidad Torreón. Rev Tamé. 2014;3:264-70.
18. Viniegra-Velázquez L. El progreso y la educación En: Educación y crítica. El proceso de elaboración del conocimiento. México: Editorial Paidós Mexicana; 2002. p. 83-98.

19. Chiecher AC, Donolo DS, Corica JL. Entornos virtuales de aprendizaje: nuevas perspectivas de estudio e investigaciones. Mendoza: Editorial Virtual Argentina; 2013.

20. Chang A, Chou CL, Teherani A, et al. Clinical skills-related learning goals of senior medical students after performance feedback. Med Educ. 2011;45:878-885. (Consultado el 25 de enero de 2016.) Disponible en: http://onlinelibrary.wiley.com/doi/10.1111/j.1365-2923.2011.04015.x/ epdf.

21. Viniegra-Velázquez L. El desafío de la educación médica en el Instituto Mexicano del Seguro Social. Cómo constituirse en la avanzada de la superación institucional. Rev Med Inst Mex Seguro Soc. 2005;43:305-21.

22. Sandars J, Cleary TJ. Self-regulation theory: applications to medical education: AMEE Guide No. 58. Medical Teacher. 2011;33:875-86.

23. González-López E, García-Lázaro I, Blanco-Alfonso A, et al. Aprendizaje basado en la resolución de problemas: una experiencia práctica. Educ Med. 2010:13:15-24.

24. Spencer J. ABC of learning and teaching in medicine. BMJ. 2003; 326:591-4.

25. Brydges $R$, Peets $A$, Issenberg $B$, et al. Divergence in student and educator conceptual structures during auscultation training. Med Educ. 2013;47:198-209.

26. Sandars J. When I say self-regulated learning. Med Educ. 2013;47:11623.

27. Wayane DB, Didwania A, Feinglass J, et al. Simulation based education improves quality of care during cardiac arrest team responses at an academic teaching hospital. American College of Chest Physicians. Chest. 2008;133:156-61. 


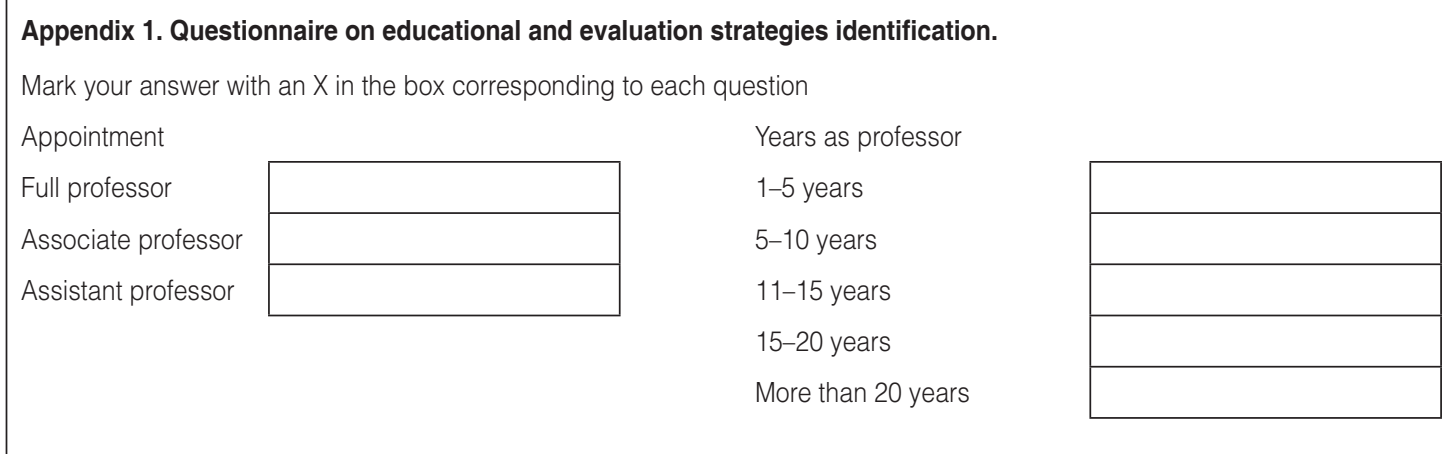

Specialty

In the courses, you teach, indicate how often do you carry out the following activities
a) I expose topics
b) I organize the students to expose topics
c) I dictate
c) I organize group dynamics
d) I ask questions about previously addressed subjects
e) I ask the students to discuss on topics exposed by me
f) I ask the students to discuss based on previous readings

How often do you use the following teaching strategies in the courses you teach?
a) Advance organizers
b) Summaries
c) Conceptual maps
d) Illustrations
e) Diagrams
f) Synoptic charts
g) Analogies
h) Demonstrations
i) Problem-based learning
j) Analysis of cases
k) Simulation

To evaluate your students' performance in theoretical aspects, indicate how often do you employ the following procedures
a) Extra-class works
b) Evidence portfolio
c) Examinations
d) Conceptual maps
e) Exposition of topics by students
f) Participation in class
g) Resolution of study guides

\begin{tabular}{|l|l|l|l|}
\hline Never & Almost never & Almost always & Always \\
\hline & & & \\
\hline & & & \\
\hline & & & \\
\hline & & & \\
\hline & & & \\
\hline & & & \\
\hline & & & \\
\hline
\end{tabular}

\begin{tabular}{|l|l|l|l|}
\hline Never & Almost never & Almost always & Always \\
\hline & & & \\
\hline & & & \\
\hline & & & \\
\hline & & & \\
\hline & & & \\
\hline & & & \\
\hline & & & \\
\hline & & & \\
\hline & & & \\
\hline & & & \\
\hline
\end{tabular}

\begin{tabular}{|l|l|l|l|}
\hline Never & Almost never & Almost always & Always \\
\hline & & & \\
\hline & & & \\
\hline & & & \\
\hline & & & \\
\hline & & & \\
\hline & & & \\
\hline
\end{tabular}

